\title{
Front Matter: Volume 8922
}

, "Front Matter: Volume 8922," Proc. SPIE 8922, IX International Seminar on Medical Information Processing and Analysis, 892201 (19 November 2013); doi: $10.1117 / 12.2048808$

SDIE Event: IX International Seminar on Medical Information Processing and SPIE. Analysis, 2013, Mexico City, Mexico 


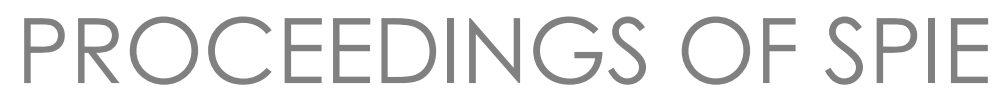

\title{
IX International Seminar on \\ Medical Information Processing and Analysis
}

\author{
Jorge Brieva \\ Boris Escalante-Ramírez \\ Editors
}

\section{1-14 November 2013 \\ Mexico City, Mexico}

Organized by

Universidad Nacional Autónoma de México (Mexico)

Universidad Panamericana (Mexico)

Sponsored by

Universidad Panamericana (Mexico)

Universidad Nacional Autónoma de México (Mexico)

Universidad Nacional de Colombia (Colombia)

Published by

SPIE 
The papers included in this volume were part of the technical conference cited on the cover and title page. Papers were selected and subject to review by the editors and conference program committee. Some conference presentations may not be available for publication. The papers published in these proceedings reflect the work and thoughts of the authors and are published herein as submitted. The publisher is not responsible for the validity of the information or for any outcomes resulting from reliance thereon.

Please use the following format to cite material from this book:

Author(s), "Title of Paper," in IX International Seminar on Medical Information Processing and Analysis, edited by Jorge Brieva, Boris Escalante-Ramírez, Proceedings of SPIE Vol.8922 (SPIE, Bellingham, WA, 2013) Article CID Number.

ISSN: 0277-786X

ISBN: 9780819498090

\section{Published by}

\section{SPIE}

P.O. Box 10, Bellingham, Washington 98227-0010 USA

Telephone +1 3606763290 (Pacific Time) · Fax +1 3606471445

SPIE.org

Copyright @ 2013, Society of Photo-Optical Instrumentation Engineers.

Copying of material in this book for internal or personal use, or for the internal or personal use of specific clients, beyond the fair use provisions granted by the U.S. Copyright Law is authorized by SPIE subject to payment of copying fees. The Transactional Reporting Service base fee for this volume is $\$ 18.00$ per article (or portion thereof), which should be paid directly to the Copyright Clearance Center (CCC), 222 Rosewood Drive, Danvers, MA 01923. Payment may also be made electronically through CCC Online at copyright.com. Other copying for republication, resale, advertising or promotion, or any form of systematic or multiple reproduction of any material in this book is prohibited except with permission in writing from the publisher. The CCC fee code is 0277-786X/13/\$18.00.

Printed in the United States of America.

Publication of record for individual papers is online in the SPIE Digital Library.

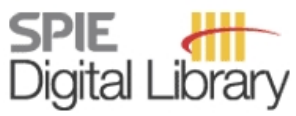

SPIEDigitalLibrary.org

Paper Numbering: Proceedings of SPIE follow an e-First publication model, with papers published first online and then in print and on CD-ROM. Papers are published as they are submitted and meet publication criteria. A unique, consistent, permanent citation identifier (CID) number is assigned to each article at the time of the first publication. Utilization of CIDs allows articles to be fully citable as soon as they are published online, and connects the same identifier to all online, print, and electronic versions of the publication. SPIE uses a six-digit CID article numbering system in which:

- The first four digits correspond to the SPIE volume number.

- The last two digits indicate publication order within the volume using a Base 36 numbering

system employing both numerals and letters. These two-number sets start with 00, 01, 02, 03, 04, 05, 06, 07, 08, 09, 0A, 0B ... 0Z, followed by 10-1Z, 20-2Z, etc.

The CID Number appears on each page of the manuscript. The complete citation is used on the first page, and an abbreviated version on subsequent pages. Numbers in the index correspond to the last two digits of the six-digit CID Number. 


\title{
Contents
}

\author{
ix Conference Committee \\ xiii Introduction
}

\section{SESSION 1 CARDIAC IMAGING 1}

892202 Sparse based optical flow estimation in cardiac magnetic resonance images [8922-19] E. Ibarra, R. Medina, Univ. de Los Andes (Venezuela)

892203 A novel right ventricle segmentation strategy using local spatio-temporal MRI information with a prior regularizer term [8922-29]

A. Atehortúa, F. Martínez, E. Romero, Univ. Nacional de Colombia (Colombia)

892204 Automated classification of LV regional wall motion based on spatio-temporal profiles from cardiac cine magnetic resonance imaging [8922-33]

J. Mantilla, INSERM (France), Univ. de Rennes (France), and Univ. de Los Andes

(Venezuela); M. Garreau, J.-J. Bellanger, INSERM (France) and Univ. de Rennes 1 (France);

J. L. Paredes, Univ. de Los Andes (Venezuela)

\section{SESSION 2 CARDIAC IMAGING 2}

892205 Evaluation of a motion artifacts removal approach on breath-hold cine-magnetic resonance images of hypertrophic cardiomyopathy subjects [8922-57]

J. Betancur, A. Simon, INSERM (France) and LTSI, CNRS, Univ. de Rennes 1 (France); F. Schnell, INSERM (France), LTSI, CNRS, Univ. de Rennes 1 (France), and Lab. de Physiologie Médicale, CNRS, Univ. de Rennes 1 (France); E. Donal, INSERM (France), LTSI, CNRS, Univ. de Rennes 1 (France), and CHU Rennes, Servide de Cardiologie et Maladies Vasculaires (France); A. Hernández, M. Garreau, INSERM (France) and LTSI, CNRS, Univ. de Rennes 1 (France)

892206 Optical flow estimation of the heart's short axis view using a perceptual approach [8922-58]

E. Moya-Albor, Univ. Panamericana (Mexico) and Univ. Nacional Autónoma de México (Mexico); B. Escalante-Ramírez, E. Vallejo, Univ. Nacional Autónoma de México (Mexico)

892207 Towards an atrio-ventricular delay optimization assessed by a computer model for cardiac resynchronization therapy [8922-59]

D. Ojeda, V. Le Rolle, K. Tse Ve Koon, INSERM (France) and LTSI, CNRS, Univ. de Rennes 1 (France); C. Thebault, E. Donal, INSERM (France), LTSI, CNRS, Univ. de Rennes 1 (France), and CHU Rennes, Service de Chirurgie Thoracique et de Chirurgie Vasculaire, Rennes (France); A. I. Hernández, INSERM (France) and LTSI, CNRS, Univ. de Rennes 1 (France) 
892208 Extracting regional brain patterns for classification of neurodegenerative diseases [8922-31]

A. Pulido, A. Rueda, E. Romero, Univ. Nacional de Colombia (Colombia)

892209 A multiscale method for a robust detection of the default mode network [8922-35] K. Baquero, Univ. Nacional de Colombia (Colombia); F. Gómez, Univ. Central de Colombia (Colombia); C. Cifuentes, Univ. Nacional de Colombia (Colombia); P. Guldenmund, A. Demertzi, A. Vanhaudenhuyse, O. Gosseries, Univ. de Liège and Univ. du Sart-Tilman (Belgium); J.-F. Tshibanda, Univ. de Liege (Belgium); Q. Noirhomme, S. Laureys, Univ. of Liege and Univ. du Sart-Tilman (Belgium); A. Soddu, Western Univ. (Canada); E. Romero, Univ. Nacional de Colombia (Colombia)

8922 0A Detecting multiple sclerosis lesions with a fully bioinspired visual attention model [8922-60] J. Villalon-Reina, Univ. of Southern California (United States); R. Gutierrez-Carvajal, Univ. Nacional de Colombia (Colombia); P. M. Thompson, Univ. of Southern California (United States); E. Romero-Castro, Univ. Nacional de Colombia (Colombia)

8922 OB An automatic search of Alzheimer patterns using a nonnegative matrix factorization [8922-4]

D. L. Giraldo, J. D. García-Arteaga, E. Romero, Univ. Nacional de Colombia (Colombia)

\section{SESSION 4 BIOSIGNAL AND BIOIMAGE 1}

8922 OC A threshold-based approach for muscle contraction detection from surface EMG signals [8922-49]

G. Morantes, Univ. Nacional Experimental del Táchira (Venezuela) and Univ. Simon Bolivar (Venezuela); G. Fernández, M. Altuve, Univ. Simón Bolívar (Venezuela)

8922 OD Blind separation of multiple physiological sources from a single-channel recording: a preprocessing approach for antenatal surveillance [8922-36]

A. Jiménez-González, Univ. Autónoma Metropolitana-Iztapalapa (Mexico); C. J. James, Univ. of Warwick (United Kingdom)

8922 OE Investigation into the efficacy of generating synthetic pathological oscillations for domain adaptation [8922-45]

R. Lewis, Univ. of Colorado at Colorado Springs (United States) and Univ. of Colorado, Denver (United States); J. Ellenberger, C. Williams, Univ. of Colorado at Colorado Springs (United States); A. M. White, Univ. of Colorado, Denver (United States)

8922 OF Preliminary results in large bone segmentation from 3D freehand ultrasound [8922-56] Z. Fanti, F. Torres, F. Arámbula Cosío, Univ. Nacional Autónoma de México (Mexico) 
8922 OG Non-rigid registration based on local uncertainty quantification and fluid models for multiparametric MR images [8922-25]

I. Reducindo, Univ. Autónoma de San Luis Potosí (Mexico); A. R. Mejia-Rodriguez, Institute of Molecular Bioimaging and Physiology, CNR (Italy) and Politecnico di Milano (Italy); E. R. Arce-Santana, D. U. Campos-Delgado, Univ. Autónoma de San Luis Potosí (Mexico); G. Rizzo, Institute of Molecular Bioimaging and Physiology, CNR (Italy)

$8922 \mathrm{OH} \quad$ Wavelet denoising of multiframe optical coherence tomography data using correlation analysis [8922-3]

W. Habib, A. M. Siddiqui, I. Touqir, National Univ. of Sciences and Technology (Pakistan)

\section{SESSION $6 \quad$ IMAGING FOR CANCER THERAPY 1}

8922 Ol Characterization of architectural distortion on mammograms using a linear energy detector [8922-21]

J. Alvarez, F. Narváez, Univ. Nacional de Colombia (Columbia) C. Poveda, Univ. Nacional de Colombia (Columbia) and Instituto Nacional de Cancerología (Columbia); E. Romero, Univ. Nacional de Colombia (Colombia)

8922 OK 3D freehand ultrasound for medical assistance in diagnosis and treatment of breast cancer: preliminary results [8922-55]

F. Torres, Z. Fanti, F. Arámbula Cosío, Univ. Nacional Autónoma de México (Mexico)

\section{SESSION 7 IMAGING FOR CANCER THERAPY 2}

$8922 \mathrm{OL} \quad$ How to identify rectal sub-regions likely involved in rectal bleeding in prostate cancer radiotherapy [8922-8]

G. Dréan, O. Acosta, INSERM (France) and Lab. de Traitement du Signal et de l'Image, CNRS, Univ. de Rennes 1 (France); J. D. Ospina, INSERM (France), Lab. de Traitement du Signal et de l'Image, CNRS, Univ. de Rennes 1 (France), and Univ. Nacional de Colombia (Columbia); C. Voisin, B. Rigaud, A. Simon, P. Haigron, INSERM (France) and Lab. de Traitement du Signal et de l'Image, CNRS, Univ. de Rennes 1 (France); R. de Crevoisier, INSERM (France), Lab. de Traitement du Signal et de I'Image, CNRS, Univ. de Rennes 1 (France), and Ctr. Eugène Marquis (France)

8922 OM Hybrid image representation learning model with invariant features for basal cell carcinoma detection [8922-40]

J. Arevalo, A. Cruz-Roa, F. A. González, Univ. Nacional de Colombia (Colombia)

$8922 \mathrm{ON} \quad$ Shape estimation of gastrointestinal polyps using motion information [8922-11] J. Ruano, F. Martinez, M. Gomez, E. Romero, Univ. Nacional de Colombia (Colombia)

892200 A novel atlas-based approach for MRI prostate segmentation using multiscale points of interest [8922-17]

C. Álvarez, F. Martínez, E. Romero, Univ. Nacional de Colombia (Colombia) 
8922 OP Bag-of-visual-ngrams for histopathology image classification [8922-1]

A. P. López-Monroy, M. Montes-y-Gómez, H. J. Escalante, Instituto Nacional de Astrofísica, Óptica y Electrónica (Mexico); A. Cruz-Roa, F. A. González, Univ. Nacional de Colombia (Colombia)

$89220 Q \quad$ Virtual slide mosaicing using feature descriptors and a registration consistency measure [8922-18]

D. Romo, J. Tarquino, J. D. García-Arteaga, E. Romero, Univ. Nacional de Colombia (Colombia)

\section{SESSION 9 E-HEALTH}

8922 OR Effects of the DICOM grayscale standard display function on the accuracy of medicalgrade grayscale and consumer-grade color displays for telemammography screening [8922-50]

A. J. Salazar, Univ. of Los Andes (Colombia); J. Romero, Univ. Hospital (Colombia);

O. Bernal, Univ. of Los Andes (Colombia); A. Moreno, Univ. Hospital (Colombia); S. Velasco,

$X$. Díaz, Univ. of Los Andes (Colombia)

8922 OS Usability evaluation of a mobile tool to support prenatal examination [8922-42]

J. C. Leon, A. Aponte, S. Vega, E. Romero, Univ. Nacional de Colombia (Colombia)

8922 OT Concurrent access to a virtual microscope using a web service oriented architecture [8922-10]

G. Corredor, Univ. Nacional de Colombia (Colombia); M. Iregui, Univ. Militar Nueva Granada (Colombia); V. Arias, E. Romero, Univ. Nacional de Colombia (Colombia)

\section{POSTER SESSION}

$8922 \mathrm{OU}$ Influence of signals length and noise in power spectral densities computation using HilbertHuang Transform in synthetic HRV [8922-16]

M. G. Rodríguez, Univ. Simón Bolívar (Venezuela) and Univ. Católica Andrés Bello (Venezuela); M. Altuve, C. Lollett, S. Wong, Univ. Simón Bolívar (Venezuela)

8922 OV QT correction formulas and laboratory analysis on patients with metabolic syndrome and diabetes [8922-52]

S. Wong, P. Rivera, Univ. Simón Bolívar (Venezuela); M. G. Rodríguez, Univ. Simón Bolívar (Venezuela) and Univ. Católica Andrés Bello (Venezuela); É. Severeyn, M. Altuve, Univ. Simón Bolívar (Venezuela)

8922 OW A grid computing framework for high-performance medical imaging [8922-9] G. Mañana Guichón, E. Romero Castro, Univ. Nacional de Colombia (Colombia)

8922 OX Filtering and left ventricle segmentation of the fetal heart in ultrasound images [8922-26] L. Vargas-Quintero, B. Escalante-Ramírez, Univ. Nacional Autónoma de México (Mexico) 
8922 OY Comparative study of variational and level set approaches for shape extraction in cardiac CT images [8922-27]

B.-J Leiner, B. Escalante-Ramírez, E. Vallejo, Univ. Nacional Autónoma de México (Mexico)

$89220 Z$ A string matching shape prior to constraint the level set evolution for the segmentation of $\mathrm{x}$-ray coronary angiography [8922-48]

J. Brieva, Univ. Panamericana (Mexico)

892210 Local image registration a comparison for bilateral registration mammography [8922-32] J. M. Celaya-Padilaa, J. Rodriguez-Rojas, V. Trevino, J. G. G. Tamez-Pena, ITESM (Mexico)

892211 A probabilistic model of emphysema based on granulometry analysis [8922-24] J. V. Marcos, Spanish National Research Council (Spain); R. Nava, Univ. Nacional Autónoma de México (Mexico); G. Cristobal, Spanish National Research Council (Spain); A. Munoz-Barrutia, Univ. of Navarra (Spain); B. Escalante-Ramírez, Univ. Nacional Autónoma de México (Mexico); C. Ortiz de Solórzano, Univ. of Navarra (Spain)

892212 Simulation and evaluation of the strain of female pelvic organs with mass-spring and finiteelements models [8922-38]

R. Khelfi, M. Rahim, B. Ratni, A. Rabahi, M.-E. Bellemare, LSIS, CNRS, Aix-Marseille Univ. (France)

892213 Knee cartilage segmentation using active shape models and contrast enhancement from magnetic resonance images [8922-39]

G. González, B. Escalante-Ramírez, Univ. Nacional Autónoma de México (Mexico)

892214 Segmentation of knee cartilage by using a hierarchical active shape model based on multi-resolution transforms in magnetic resonance images [8922-43]

M. León, B. Escalante-Ramirez, Univ. Nacional Autónoma de México (Mexico)

Author Index 
Proc. of SPIE Vol. $8922892201-8$

Downloaded From: https://www.spiedigitallibrary.org/conference-proceedings-of-spie on 26 Apr 2023 Terms of Use: https://www.spiedigitallibrary.org/terms-of-use 


\section{Conference Committee}

\section{Conference Chairs}

Fernando Arámbula, Universidad Nacional Autónoma de México (México)

Jorge Brieva, Universidad Panamericana (México)

María Victoria Carreras, Universidad Panamericana (México)

Boris Escalante-Ramírez, Universidad Nacional Autónoma de México (Mexico)

Félix Martínez, Universidad Panamericana (México)

Verónica Medina, Universidad Nacional Autónoma de México (México)

Eduardo Romero, Universidad Nacional de Colombia (Columbia)

\section{Conference Review Committee}

Mario Acevedo, Universidad Panamericana (Mexico)

Oscar Acosta, Université of Rennes 1 (France)

Miguel Altuve, Universidad Simón Bolívar (Venezuela)

Joaquín Azpiroz, Universidad Autónoma Metropolitana (Mexico)

Marc-Emmanuel Bellemare, LSIS (France)

Antonio Bravo, Universidad Nacional Experimental del Táchira

(Venezuela)

Jorge Camargo, Universidad Nacional de Colombia (Colombia)

Alfredo Hernández, LTSI, INSERM (France)

Fabio González, Universidad Nacional de Colombia (Colombia)

Juan Carlos Caicedo, Universidad Nacional de Colombia (Colombia)

Gloria Díaz, Universidad Nacional de Colombia (Colombia)

Fabián García, Universidad Nacional Autónoma de México (Mexico)

Juan David García, Universidad Nacional de Colombia (Colombia)

Crescencio García, Universidad Nacional Autónoma de Mexico (México)

Edgar Garduño, Universidad Nacional Autónoma de México (Mexico)

Francisco Gómez, Universidad Nacional de Colombia (Colombia)

Ricardo Gutierrez, Universidad Nacional de Colombia (Colombia)

Nidiyare Hevia, Universidad Nacional Autónoma de México (Mexico)

Marcela Iregui, Universidad Militar (Colombia)

Juan Ramón Jiménez, Universidad Autónoma Metropolitana (Mexico)

Alexandra La Cruz, Universidad Simón Bolivar (Venezuela)

Natasha Lepore, Children Hospital, Los Angeles (United States)

Ruben Medina, Universidad de los Andes (Venezuela)

Luciana Nedel, Universidad de Río Grande do Sul (Brasil)

Oscar David Robles, Universidad Rey Juan Carlos (España)

Alfredo Mantilla, Tecnológico de Monterrey (México)

Alexander Cerquera, Universidad Antonio Nariño (Colombia)

Norberto Malpica, Universidad Rey Juan Carlos (España)

Gabriel Mañana, Universidad Nacional de Colombia (Colombia) 
Antoine Manzanera, ENSTA (France)

Ricardo Marcelín, Universidad Autónoma Metropolitana (Mexico)

Elena Martínez, Universidad Nacional Autónoma de México (Mexico)

Lucía Medina, Universidad Nacional Autónoma de México (Mexico)

Ernesto Moya, Universidad Panamericana (Mexico)

Javier Pascau, HGGM (Spain)

Alfonso Prieto, Universidad Autónoma Metropolitana (Mexico)

Katya Rodríguez, Universidad Nacional Autónoma de Mexico (México)

Andrea Rueda, Universidad Nacional de Colombia (Colombia)

Emilio Sacristán, Universidad Autónoma Metropolitana (Mexico)

Antonio Salazar, Universidad de los Andes (Colombia)

Emanuel Schiavi, Universidad Rey Juan Carlos (España)

Arturo Vera, CINVESTAV (Mexico)

Ramiro Velazquez, Universidad Panamericana (Mexico)

Sara Wong, Universidad Simón Bolívar (Venezuela)

Oscar Yañez, Universidad Autónoma Metropolitana (Mexico)

Maria Zuluaga, University College London (United Kingdom)

\section{Session Chairs}

1 Cardiac Imaging 1

Boris Escalante-Ramirez, Universidad Nacional Autónoma de México (Mexico)

2 Cardiac Imaging 2

Jorge Brieva, Universidad Panamericana (Mexico)

3 Brain Imaging

Verónica Medina, Universidad Autónoma Metropolitana (Mexico)

$4 \quad$ Biosignals and Bioimage 1

Eduardo Romero, Universidad Nacional de Colombia (Colombia)

5 Biosignal and Bioimage 2

Eduardo Romero, Universidad Nacional de Colombia (Colombia)

$6 \quad$ Imaging for Cancer Therapy 1

Boris Escalante-Ramirez, Universidad Nacional Autónoma de México (Mexico)

$7 \quad$ Imaging for Cancer Therapy 2

Jorge Brieva, Universidad Panamericana (Mexico)

8 Digital Pathology

Fernando Arámbula, Universidad Nacional Autónoma de México (Mexico) 
9 e-Health

Fernando Arámbula, Universidad Nacional Autónoma de México (Mexico)

10 Poster Session: Cardiac Imaging, Biosignals and Bioimage, Brain Image, Imaging for Cancer Therapy

Fernando Arámbula, Universidad Nacional Autónoma de México

(Mexico)

Jorge Brieva, Universidad Panamericana (Mexico)

Maria Victoria Carreras, Universidad Panamericana (Mexico)

Boris Escalante, Universidad Nacional Autónoma de México (Mexico)

Felix Martinez, Universidad Panamericana (Mexico)

Verónica Medina, Universidad Autónoma Metropolitana (Mexico)

Eduardo Romero, Universidad Nacional de Colombia (Colombia)

Plenary Session Chairs

1 Medical Image Computing, Cloud Computing, and Scalability: Which

Way?

Gabriel Mañana, Universidad Nacional de Colombia (Colombia)

2 Patient-Specific Therapy Delivery by Implantable Devices Through

Advanced Data Processing and Physiological Modeling

Alfredo Hernández, LTSI, INSERM (France)

3 Brain MRI Data Analyses for Research and the Clinic

Natasha Leporé, Children Hospital, LA (United States)

4 Personalization and Optimization of Medical Treatments With in

Silicomedicine: Illustration in Patient-Specific Computational Modeling of Cardiac Electrophysiology

Karim Lekadir, Universitat Pompeu Fabra, Barcelona (Spain)

5 Of Cancer in Mice and Men, One Cell at a Time

Carlos Ortiz de Solórsano, Universidad de Navarra (Spain)

6 Medical Image Processing with Computational Models of Visual

Perception

Boris Escalante-Ramirez, Universidad Nacional Autónoma de México (Mexico)

$7 \quad$ Non-Invasive Imagenology as an Aid for Clinical Diagnosis

Crescencio García-Segundo, Universidad Nacional Autónoma de México (Mexico)

8 Analysis and Processing of Brain Information

Verónica Medina Bañuelos, Universidad Autónoma Metropolitana (Mexico) 
9 Magnetic Resonance Imaging and Image Processing in Complex Studies of Cellular Metabolism in the Brain

Joaquín Azpiroz, Universidad Autónoma Metropolitana (Mexico)

10 Medical Image Analysis and Computer Assisted Surgery at CCADET, Universidad Nacional Autónoma de México

Fernando Arámbula, Universidad Nacional Autónoma de México (Mexico)

11 On the Search of Functional and Structural Biomarkers

Eduardo Romero, Universidad Nacional de Colombia (Colombia)

12 Prostate Cancer Radiotherapy

Oscar Acosta, LTSI, Université of Rennes 1 (France) 


\section{Introduction}

Welcome to the IX International Seminar on Medical Information Processing and Analysis!

In this occasion, the Seminar will be held in Mexico for the first time. We have succeeded in our attempt to combine several aspects that will turn this conference into a memorable academic event: a high quality review process, twelve invited Keynote Speakers internationally recognized in their research areas and a magnific venue to hold meetings, and discussions between participants.

Oral and poster sessions include contributions in wide areas such as Bio-signals and Bio-image (signal and image analysis and interpretation, signal/image generation and reconstruction, segmentation and grouping), e-Health (telemedicine, medical devices and medical information retrieval), and Machine Learning. In addition, we have gathered an important number of papers that allowed us to include more specific topic areas, namely Brain Imaging, Cardiac Imaging, and Imaging for Cancer Therapy.

This conference has traditionally had a regional character but for its ninth version we will have participants from North and South America, Europe and Asia: This is evidence of the high academic quality of the event as well as a sign of the growing international interest for this event that we hope will take this event to venues outside the Latin American region in the near future.

Finally, Mexico City is an interesting place rich in tourism and culture, with more than one hundred museums, several UNESCO World Heritage Sites, a large variety of cultural and artistic activities, typical and international food and many astonishing historical pre-Columbian places.

We hope that all the attendees enjoy the conference, its technical program, and the city of Mexico!

Jorge Brieva Boris Escalante-Ramírez 
Proc. of SPIE Vol. $8922892201-14$

Downloaded From: https://www.spiedigitallibrary.org/conference-proceedings-of-spie on 26 Apr 2023 Terms of Use: https://www.spiedigitallibrary.org/terms-of-use 